\title{
Antibacterial Properties of Local Malaysian Trigona Sp. Honey Towards Different of Pathogenic Bacteria in Vitro
}

\author{
Fawzia Jassim Shalsh ${ }^{1}$, Ahmed Mohammed Khalaf ${ }^{2}$, Mohammed Hafiz ${ }^{3}$, Imad Ibrahim Ali \\ Al-Sultan ${ }^{4}$ \\ ${ }^{1}$ Industrial Microbiology Dept. Directorate of Agricultural Research /Science and \\ Technology, Iraq. \\ ${ }^{2}$ Faculty of Allied Medical Science, Al-Ahliyya Amman University -Jordan \\ ${ }^{3}$ Faculty of Veterinary Medicine, University Malaysia Kelantan. \\ ${ }^{4}$ Faculty of Medicine, Lincoln University College, Malaysia. \\ ${ }^{1}$ Corresponding author: fawzia.jassim2015@gmail.com
}

\begin{abstract}
Honey is one of the oldest natural medicines known with a very high therapeutic value. Nowadays, in the medical field, several important therapeutic effects of honey have been elucidated. This study was conducted to reveal the antimicrobial activity of the commercially available local Malaysian Trigona sp. honey towards different pathogenic bacteria specifically Staphylococcus aureus, Streptococcus pyogenes, Escherichia coli, and Salmonella typhimurium. The Minimum inhibitory concentration and Minimum bactericidal concentration were determined by the disc-diffusion test and agar well diffusion test. Different concentration of the honey was tested in the disc-diffusion and agar well diffusion test. The results of these tests were in terms of Inhibition zone diameter. The results obtained from the current study are the dilution of different concentration of honey from Trigona sp. are very significant because the only net concentration of both of honey Trigon a sp. possessed antimicrobial properties in term of Minimum inhibitory concentration) and Minimum bactericidal concentration. The result also can say that Trigona sp. honey possessed antibacterial properties and can be used as alternative medicine in the veterinary field in the future.
\end{abstract}

Keywords: Honey, Trigona sp., pathogenic bacteria, alternative medicine.

\section{Introduction}

Honey is one of the oldest natural medicines known with a very high therapeutic value. Nowadays, in the medical field, several important therapeutic effects of honey have been elucidated. Staphylococcus aureus and Streptococcus pyogenes are commonly known to be the primary cause of delayed healing and infection in wounds (Caldwell, 2020). The arisen of multiple drug resistance by nosocomial bacteria, P. aeruginosa, and $S$. aureus has been a huge concern internationally and an obstacle in the pharmaceutical industry (Frieden, 2010). Staphylococcus. aureus are the most robust and virulent microbes among the Staphylococci family that infect humans. Its tendency to develop antibiotic resistance has been a huge concern to human health. Moreover, externally acquired Staphylococci bacteria can cause life-

\section{Dates:}

Received: 27 February 2021

Accepted 03 April 2021

Published: 30 June 2021 
threatening complications like pneumonia, endocarditis, meningitis, and osteomyelitis when inoculated into open wounds (David and Daum, 2010). Escherichia. coli besides its role in gastrointestinal infections, E. coli can cause infections of the urogenital tract and systemic disease in dogs and cats. Extra-intestinal pathogenic E. coli strains from dogs and cats belong to a limited number of serotypes and clonal groups and are frequently found as a part of the normal gut flora of these animals (Aibinu et al, 2004). Salmonellosis is an infectious disease of humans and animals which are caused by Salmonella mainly S. enterica and S. bongori. Infection of Salmonella is known as host-specific such as $S$. Typhiin humans (causes typhoid fever), S. Abortusovis in sheep, S. Choleraesuisin pigs, and S. Dublin in cattle S. Pullorum in avian. While S. Typhimurium and S. Albany are known to cause only gastroenteritis (Pal et al, 2020).

Honey is a rich carbohydrate syrup made by the Bees. Fructose and glucose are the major components of honey. Large numbers of compounds are also present in small quantities. Honey possessed low moisture content and water activity. Honey has been used as medicine since ancient times in many cultures. Honey has been found to heal infected surgical wounds, burns, and decubitus ulcer as published by several researchers (Bunza et al, 2019; Divya et al., 2018; Abou Zekry et al, 2020). The previous study showed that stingless bee honey can act as an anti-inflammatory (Borsato et al, 2014), anti-cancer (Al-Ajmi et al, 2019), antimicrobial (Kimoto and Amano, 2008; Nolan et al, 2019; Fernandes et al, 2020) and possessed antioxidant properties (Gośliński et al, 2020). In the microbiology field, honey was found to possess good antimycobacterial activity (John-Isa et al, 2019). Laboratory studies have revealed that honey is effective against Methicillin-resistant Staphylococcus aureus (MRSA), $\beta$-hemolytic Streptococci, and Vancomycin-resistant Enterococci (VRE) as reported in earlier studies (Allen et al, 1991; Lye, 2014). Other than that, geographical distribution and also different floral sources play important role in the antimicrobial activity of honey (Ali ce et al, 2011; Taormina et al, 2001).

The honey that is commonly found in Malaysia is the Tualang honey, Jungle honey, Cerung or Cerang honey, and finally the Kelulut honey (Barakhbah, 2007). Kelulut honey is produced by stingless bees from Trigona sp. Kelulut honey is increasingly receiving attention from Malaysians due to its uniquely sour taste and its flavour. The honey is produced believed to have more medical values. Research showed honey of Trigona. sp. has antimicrobial properties: high acidic value and low $\mathrm{pH}$ value: high saturation of sugar; the antimicrobial activity itself (Shahjahan et al, 2007). Even though there are many types of research about Trigona sp. worldwide. In Malaysia, there are only a few types of research about the local Malaysian honey of Trigon sp. used in the human and veterinary field. Although there are many types of research about the antibacterial activity of Malaysian honey (Tumin et al, 2005; Al-kafaween et al, 2020), many of them are not used all the types of honey available in Malaysia. Although recently there were researches of comparison of physicochemical properties of Malaysia Trigona sp. honey in Peninsular Malaysia, there were no comparison researches about the commercially available Malaysian honey of Trigona sp. towards different pathogenic bacteria.

Antimicrobial resistance is becoming a global issue nowadays. So, alternative treatment should be immediately discovered. One of the alternative substances to replace antimicrobials substances is honey. Until now, there were few studies of the antibacterial properties of 
different brands of Kelulut honey available in Malaysia on different pathogenic microorganisms. The objectives of this research were to study and compare the antibacterial activity of the different brands of commercially available Kelulut honey in Malaysia.

\section{Honey samples}

\section{Materials and Methods}

The honey samples (K1-Kelulut Honey Brand 1 and K2-Kelulut Honey Brand 2) were collected from commercial stores located in Kota Bharu, Kelantan, Malaysia between February 2019 and October 2019. It is multi-floral honey from stingless bees and it obtained its name from the bees producing it that are locally known as Kelulut. Kelulut bees are from the genus Trigona, the largest genus of stingless bees that are indigenous to Neotropics and Indo-Australian regions (Michener, 2007). Samples were stored in a dark place at room temperature $\left(25-35^{\circ} \mathrm{C}\right)$.

\section{Bacterial Strains}

Strains of Escherichia coli, Salmonella typhimurium, Staphylococcus aureus, and Streptococcus pyogenes were obtained from the faculty of Veterinary Medicine University Malaysia Kelantan, Malaysia.

\section{Disc diffusion method and agar well diffusion method}

Filter paper discs of $6 \mathrm{~mm}$ diameter were prepared. The discs were impregnated with the different concentrations of each honey (0, 20, 40, 60, 80, and 100\%), 0.5 McFarland standard was prepared by the method of Koneman et al, (1992) and $5 \mathrm{~mL}$ was added into a sterile test tube. An inoculum of each isolate was prepared from the subculture of bacterial suspension sterile test tube, 4-5 colonies of each isolate were emulsified in sterile normal saline, and the turbidity adjusted to $1.5 \times 10^{8} \mathrm{CFU} / \mathrm{mL}$ (corresponding to $0.5 \mathrm{McF}$ arland standers). A sterile cotton swab was dipped into the standardized bacterial suspension and used to evenly inoculate the Mueller Hinton agar plates. They were allowed to dry for 3 to 5 minutes. Thereafter, all discs were placed on the plates and pressed gently to ensure complete contact with agar. A distance of at least $15 \mathrm{~mm}$ was maintained from the edges of the plates to present overlapping of inhibition zones. Ampicillin disc $(5 \mu \mathrm{g})$ was used as a positive control. Fifteen minutes after the placement of discs, the plates were incubated for $24 \mathrm{~h}$ at $37{ }^{\circ} \mathrm{C}$. After incubation, the plates were examined, and three diameters of the inhibition zone were measured in triplicates for each isolate. For the agar well diffusion method, the well had been made by sterilized cork borer to create five well with $2.5 \mathrm{~mm}$ diameter on the agar (Bauer, 1966).

\section{Minimum inhibitory concentration (MIC).}

Both $\mathrm{K} 1$ and $\mathrm{K} 2$ honey were tested for the minimum inhibitory concentration test using the broth dilution method according to the method described by Turnidge (2007). This procedure involved the preparation of two-fold serial dilutions of antibiotics in a liquid growth medium dispensed in sterile test tubes. From each folded of serial dilution, the mixture needed to thoroughly mix. A different concentration of the test material (Ampicillin) was obtained by six rows in each containing $50,100,150,200,250$, and $300 \mathrm{mg} / \mathrm{mL}$. Then, 0.5 $\mathrm{mL}$ of bacterial suspension was filled into each tube to achieve a final concentration of $1.5 \mathrm{x}$ 
$10^{8} \mathrm{CFU} / \mathrm{mL}$. Two sets of controls were set for each tube which contained; (a) positive control consisting of broth and bacterial suspension and (b) negative control only consisting of broth. Afterward, the tubes were incubated for 24 hours incubation at $37^{\circ} \mathrm{C}$. Then, the tubes were observed for bacterial growth as evidenced by turbidity. The turbidity of MIC test tubes was measured according to absorbance at a wavelength of 600 using spectrophotometry. The lowest concentration of extracts (antibiotic) which tubes with turbidity indication was recorded as the MIC value. The average values were calculated for the MIC of the test material.

\section{Minimum bactericidal concentration (MBC)}

After identification of the MIC, inoculum from each tube was streaked into an agar plate and incubated at $37{ }^{\circ} \mathrm{C}$ for 24 hours. According to Aibinu et al, (2004), the lowest concentration that prevented bacterial growth was recorded as MBC value.

\section{Statistical analysis}

Data obtained were analyzed by one-way ANOVA by using SPSS package v.10

\section{Disc diffusion test}

\section{Results and Discussions}

The results in terms of inhibition zone diameter (IZR). The IZR of both different brands of honey was different. By establishing the column chart, quantitatively can compare the IZR of both of these honey. This also correlates with the minimum inhibitory concentration test because each of the discs also is soaked with different concentrations of honey. The disc diffusion test for 20, 40, and 60\% concentration of Kelulut honey 1 and Kelulut honey 2 showed no zone of inhibition against the selected bacteria. At $80 \%$ concentration, Kelulut honey 1 and 2 exhibited inhibition zone only against Streptococcus pyogenes $2 \pm 0.3$ and 1.5 $\pm 0.5 \mathrm{~mm}$ respectively (Fig. 1 ).

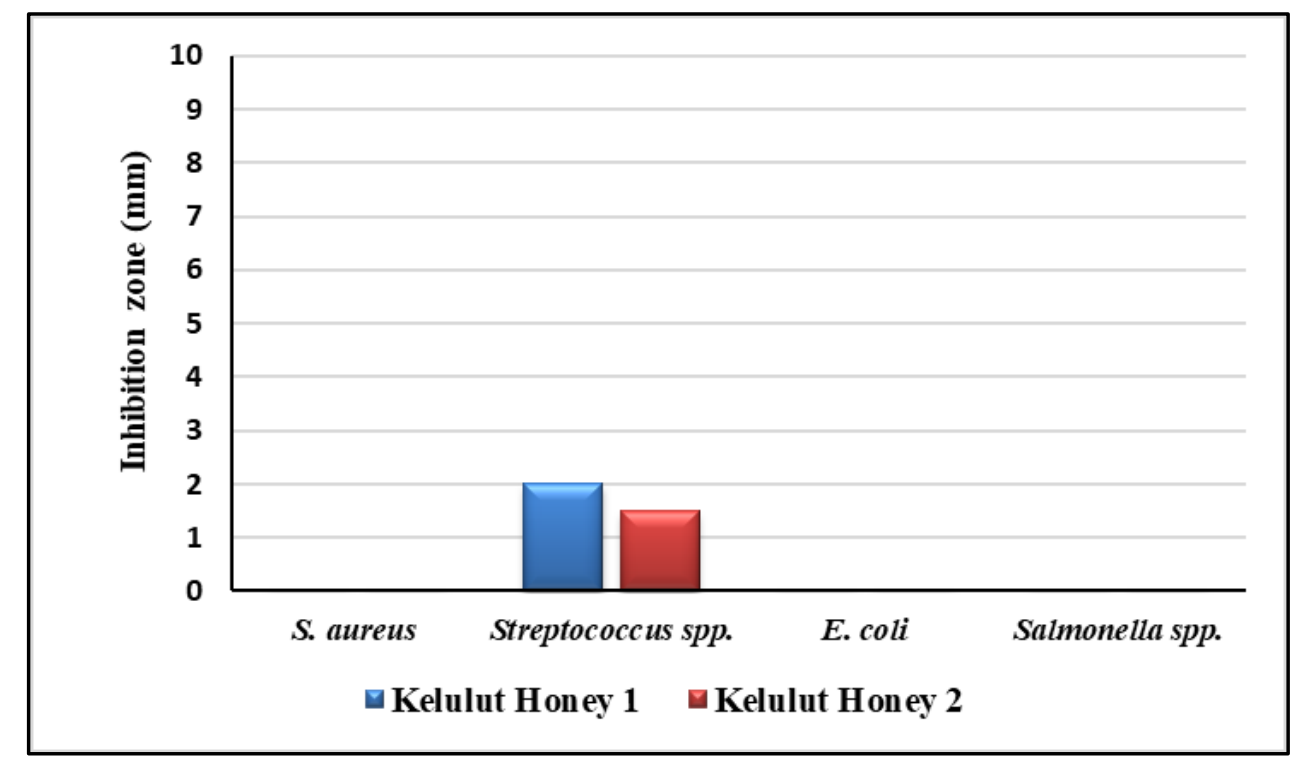

Figure 1. Inhibition Zone Diameter (mm) for $80 \%$ Concentration of Kelulut Honey 1 and 2. 
For Disc diffusion test neat $(100 \%)$ of Kelulut honey 1 exhibited better antibacterial outcome than Kelulut honey 2 and the clear zone produced by neat honey against Staphylococcus aureus and E.coli, were $3 \pm 0.5$ and $4 \pm 0.2 \mathrm{~mm}$ respectively comparing $2 \pm$ 0.5 and $3 \pm 0.5 \mathrm{~mm}$ respectively (Fig. 2).

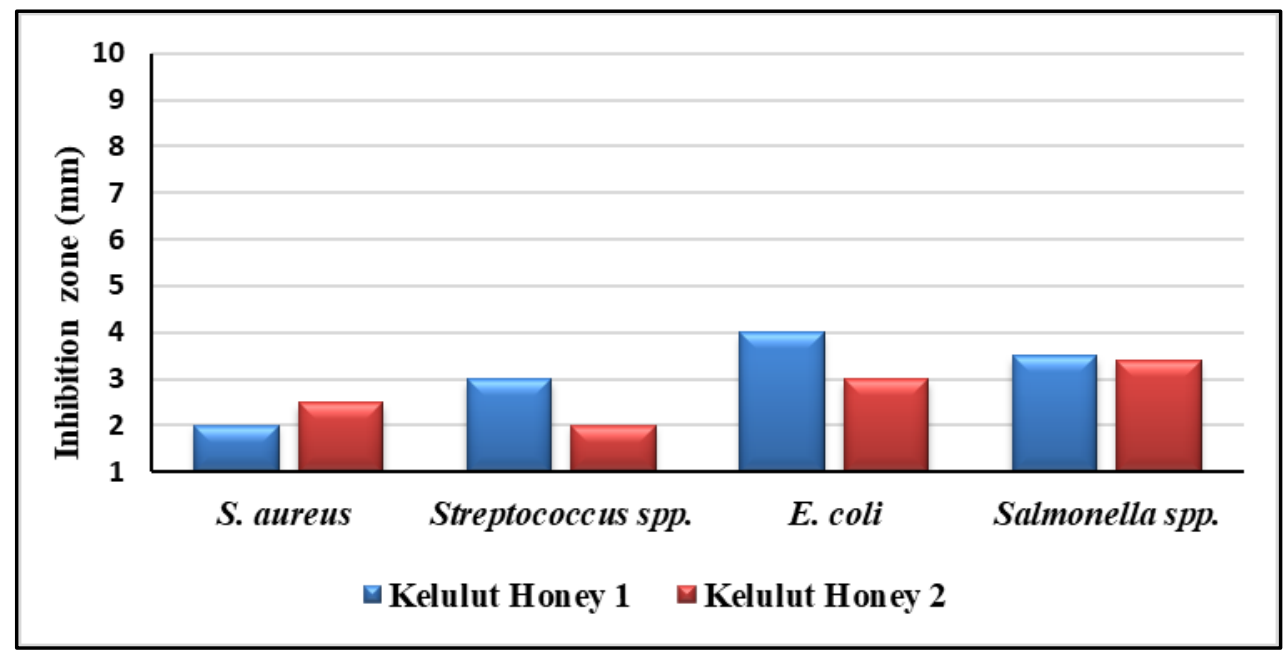

Figure 2. Inhibition zone diameter (mm) for 100\% concentration of Kelulut honey 1 and 2.

\section{Agar well diffusion test}

Agar well diffusion test for 20,40, and 60\% concentration of Kelulut honey 1and Kelulut honey 2 showed no zone of inhibition against the selected bacteria. At $80 \%$ concentration, Kelulut honey 1and 2 showed zone of inhibition against Staphylococcus aureus and Streptococcus pyogenes, Kelulut honey 1 exhibited $3 \pm 0.5$ and $2.3 \pm 0.2 \mathrm{~mm}$ respectively whereas Kelulut honey 2 exhibited inhibition zone against Staphylococcus aureus and Streptococcus pyogenes $2.4 \pm 0.6$ and $2.0 \pm 0.5 \mathrm{~mm}$ respectively (Fig. 3). For agar, well diffusion test neat of Kelulut honey 1 exhibited better antibacterial outcome than diluted honey, and the clear zone produced by neat honey against, Streptococcus pyogenes, E.coli and Salmonella typhimurium were $3.4 \pm 0.6,2.4 \pm 0.6,9.3 \pm 0.2$, and $8.1 \pm 0.4 \mathrm{~mm}$ respectively. Agar well diffusion test neat of Kelulut honey (2) exhibited better antibacterial outcome than diluted honey and the clear zone produced by neat honey Staphylococcus aureus, Streptococcus pyogenes, E.coli and Salmonella typhimurium were $3.7 \pm 0.3,1.6 \pm 0.4,8.2 \pm$ 0.3 , and $7.2 \pm 0.3 \mathrm{~mm}$ respectively (Fig. 4).

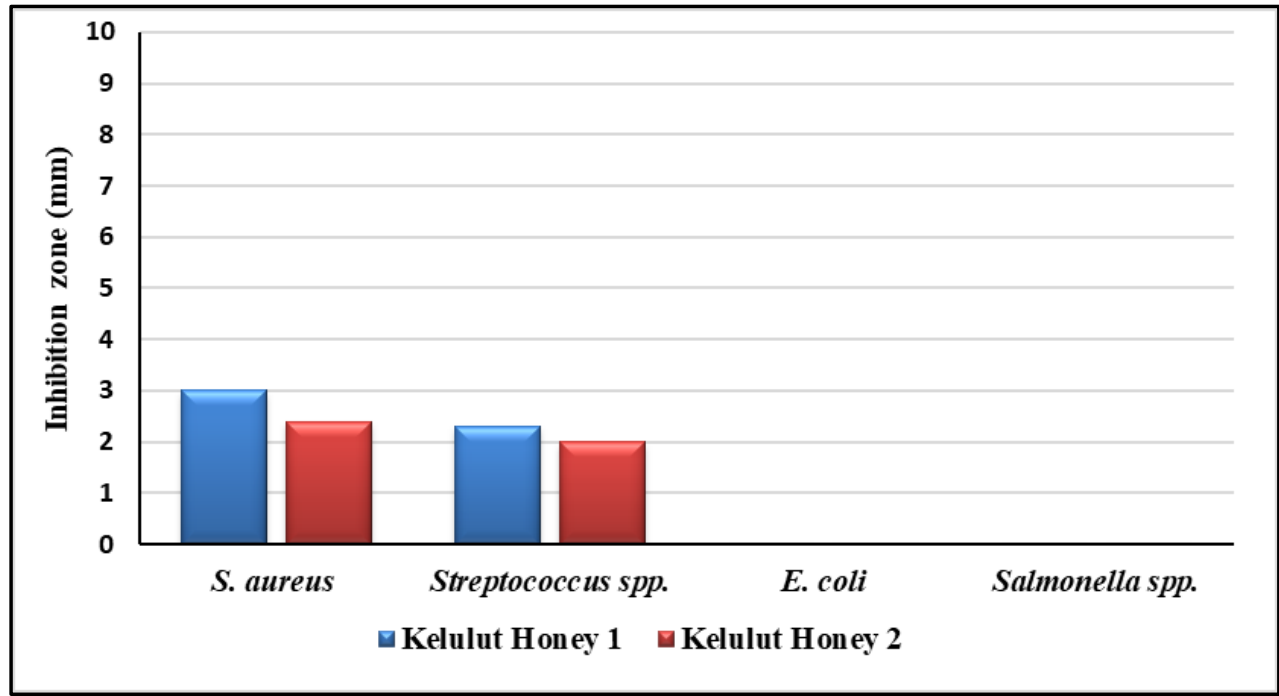


Figure 3. Inhibition zone diameter $(\mathrm{mm})$ for $80 \%$ concentration of Kelulut honey 1 and 2

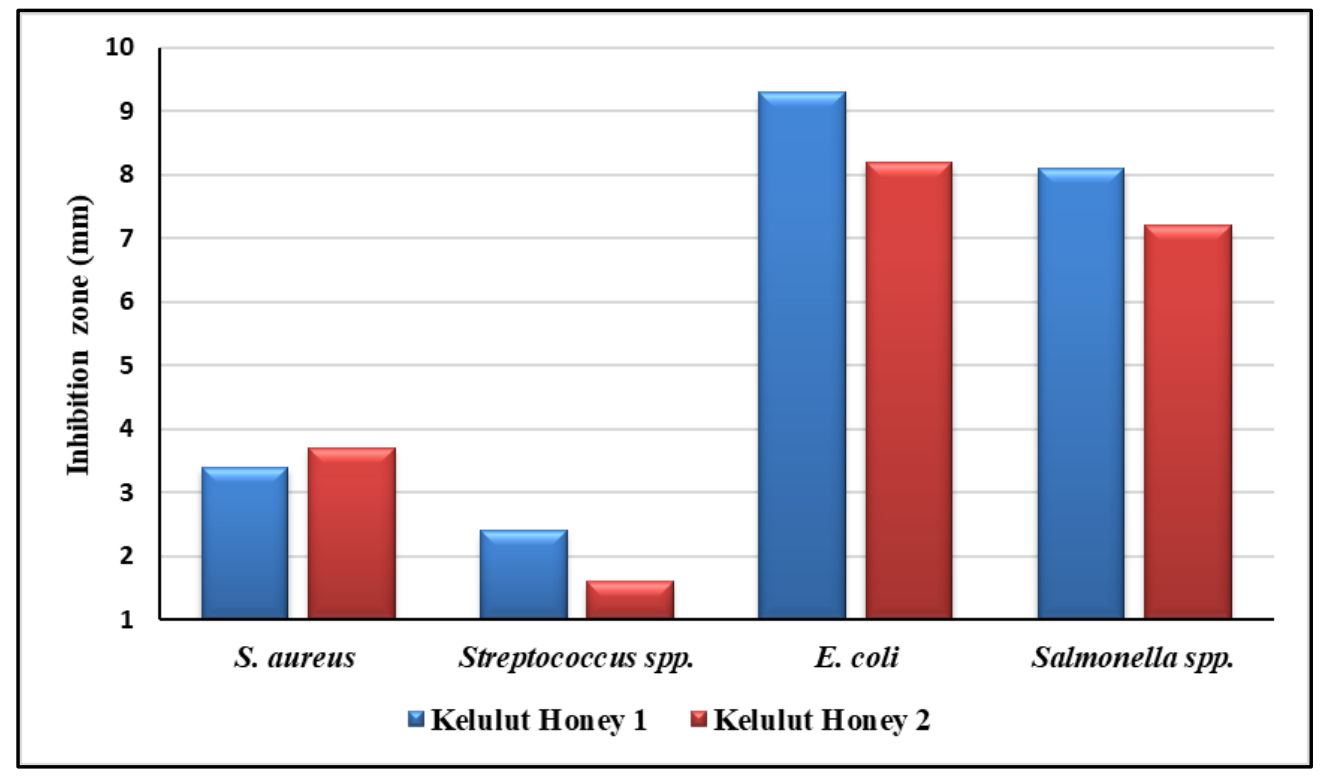

Figure 4. Inhibition zone diameter (mm) for $100 \%$ concentration of Kelulut honey 1 and 2

The current study indicated that Kelulut honey alone was less potent in inhibiting the growth of all the pathogenic bacteria Staphylococcus aureus, Streptococcus pyogenes, Escherichia coli, and Salmonella typhimurium when dilution of the honey was done regardless of the concentration. These also include both brands of the commercially available Kelulut honey. The disc diffusion test and agar well diffusion test showed no zone of inhibition was formed by the honey of Trigona alone after dilution was made. This result is in agreement with a study done by Shahjahan et al. (2007) who showed that neat honey exhibited better antibacterial outcome than diluted honey and the clear zone produced by neat honey against Salmonella typhi, Shigella sonnei, Escherichia coli, Pseudomonas aeruginosa, Staphylococcus aureus, and Streptococcus group A were 30, 28, 26, 23 and 24mm respectively. And the MIC value for the bacteria tested was between 8.5 to $70 \mathrm{mg} / \mathrm{mL}$. The efficacy of undiluted honey was superior against bacteria tested with a greater inhibitory effect than diluted honey. Another study also reported that $100 \%$ concentration of honey formed the largest zone of inhibition than 50\% honey concentration and among all the bacteria investigated, all honey concentrations showed inhibitory effect and only S. aureus showed no zone of inhibition (Al-Naama, 2009). The divergence of results might be due to several reasons such as the different botanical origins and processing methods. Honey's antibacterial efficacy is enhanced by the presence of hydrogen peroxide, an essential antibacterial enzyme that also serves as an oxidizing and sanitizing agent. (Latkal et al., 2020). Hydrogen peroxide, phenolic compounds, and other flavonoids are responsible for honey's biological activity, which includes antioxidant, antimicrobial, anti-inflammatory, antiproliferative, and anticancer (Alzahrani et al, 2012; Godocikova et al, 2020). Latkal et $a l$, (2020) reported that the concentration of honey produces total elimination of bacterial growth for E.coli 30\%, S. aureus 50\%, and Streptococcus pyogens 50\%. Furthermore, several studies also showed that $50 \%$ concentration of honey of Trigona exhibited greatest antibacterial action than other concentrations (Ewnetu et al, 2013; Eswaran et al, 2015). However, the results obtained from the present study did not correspond with other previous studies. The divergence of results might be due to several reasons such as different botanical 
origin and processing methods. Besides that, several limitations of the agar well-diffusion test were discovered including the insensitivity in detecting the low level of antimicrobial activity, variation in the experimental conditions, and permeability of nonpolar components. Thus, agar well-diffusion test may not be the most appropriate method to evaluate the antibacterial activity of honey (Kimoto-Nira and Amano, 2008).

In terms of a specific type of bacteria, the results show that the IZD for E.coli and Salmonella spp. was greater than S.aureus and Streptococcus spp. The results were applied to both the disc diffusion test and agar well diffusion test. However, the account the chemistry and biotransformation of honey must be taken after ingested by the patient. This will change the efficacy of honey in terms of antimicrobial activity. The variation in the antimicrobial potential of honey used in the present study as compared to the others might be due to differences in the growth rate of pathogens, inoculum size, and the test method itself, as well as the source of the microorganisms (Andualem, 2014). Honey is produced from many sources, and its antimicrobial activity varies greatly with origin and processing. Also, it might be the fact that the type of honey produced by honeybees is dependent on the natural vegetative flowers blooming in different seasons and different places, and thus the flowers from which bees gathered nectar to produce the honey may contribute to the difference in the antimicrobial activities of honey (Machado et al, 2019).

\section{Conclusions}

This study has proven that dilution of honey of Trigona will be decreased or eliminate its antimicrobial activity. Escherichia.coli and Salmonella spp. were more susceptible to honey of Trigona than S.aureus and Streptococcus spp. in vitro. Finally honey Trigona had a potential value to be one of the sources for medical alternative treatment to treat skin infection and gastroenteritis in animals or human but without dilution (as it is).

\section{Conflict of interests}

The authors declare no conflict of interest.

\section{Acknowledgments}

The authors are very grateful to the University Malaysia Kelantan, Faculty of Veterinary Medicine for their provided facilities, which helped to improve the quality of this work.

\section{References}

Abou Zekry, S.S., Abdellatif, A. and Azzazy, H.M. 2020. Fabrication of pomegranate/honey nanofibers for use as antibacterial wound dressings. Wound Medicine, 28:100-181. https://fount.aucegypt.edu/etds/518

Aibinu, I., Aednipekun, E. and Odugbemi, T. 2004. Emergence of quinolone resistance amongst Escherichia coli strains isolated from clinical infections in some Lagos state hospitals, in Nigeria. Nigerian JHBS 3(2): 73-78.DOI: $10.4314 /$ njhbs.v3i2.11513

Al-Ajmi, H.I.S., Al-Lawati, H.T., Rahman, M.S., Guizani, N. and Waly, M.I. 2019. Protective effects of honey bee products against oxidative stress-associated carcinogenesis in a rat model of colon cancer. CJCN 7(2):62-78. doi.org/10.14206/canad.j.clin.nutr.2019.02.05 
Alice, G.C., DeDent, A.C., Schneewind, O. and Missiakas, D. 2011. A play in four acts: Staphylococcus aureus abscess formation. Trends in Microbiology, 19(5), pp. 225-232.

Al-kafaween, M.A., Hilmi, A.B.M., Jaffar, N., Al-Jamal, H.A.N., Zahri, M.K. and Jibril, F.I. 2020. Antibacterial and antibiofilm activities of Malaysian Trigona honey against Pseudomonas aeruginosa ATCC 10145 and Streptococcus pyogenes ATCC 19615. Jordan J. Biol. Sci, 13(1):69-76. doi: doi.org/10.18502/ijm. v12i6.5031

Allen, K.L., Molan, P.C. and Reid, G.M. 1991. A survey of the antibacterial activity of some New Zealand honeys. JPP, 43(12):817-822. Doi: $10.1111 / \mathrm{j} .2042-7158.1991$.

Al-Naama, R.T. 2009. Evaluation of in-vitro inhibitory effect of honey on some microbial isolate. African J.Bacteriol. Res, 1(6):064-067. doi.org/ 10.589 7/JBR. 9000020

Alzahrani, H.A., Alsabehi, R., Boukraâ, L., Abdellah, F., Bellik, Y. and Bakhotmah, B.A. 2012. Antibacterial and antioxidant potency of floral honeys from different botanical and geographical origins. Molecules, 17(9):10540-10549. DOI: 10.3390/molecules170910540

Andualem B. 2014. Physico-chemical, microbiological and antibacterial properties of Apis mellipodae and Trigona spp. honey against bacterial pathogens. WJAS. 10(3):112-20. doi.org/10.22146/ijc.40869

Barakhbah, S.A.S.A. 2007. Honey in the malay tradition. MJMS, 14(1) p106-106.

Bauer, A. W. 1966. Antibiotic susceptibility testing by a standardized single disc method. Am J clin pathol. 45:149-158. PMID: 5325707

Beutin, L. (1999). Escherichia coli as a pathogen in dogs and cats. Veterinary research, 30(2-3), 285-298.

Borsato, D.M., Prudente, A.S., Döll-Boscardin, P.M., Borsato, A.V., Luz, C.F., Maia, B.H., Cabrini, D.A., Otuki, M.F., Miguel, M.D., Farago, P.V. and Miguel, O.G. 2014. Topical antiinflammatory activity of a monofloral honey of Mimosa scabrella provided by Melipona marginata during winter in Southern Brazil. J Med Food, 17(7):817-825. Doi.org/10.1089/jmf.2013.0024

Bunza, N.M., Kumurya, A.S., Isah, A.A., Azeez, B.A. and Nafiu, F. 2019. Comparative evaluation of the antibacterial effects of honey with standard antibiotic on bacterial isolates from wound infection. ASIAN J PHARM SCI,1-7.Doi.org/10.9734 /ajrimps/2019/v7i11

Caldwell, M. D. 2020. Bacteria and antibiotics in wound healing. Surgical Clinics, 100(4), 757-776. DOI:https://doi.org/10.1016/j.suc.2020.05.007

David, M. Z., \& Daum, R. S. 2010. Community-associated methicillin-resistant Staphylococcus aureus: epidemiology and clinical consequences of an emerging epidemic. CMR, 23(3), 616687. doi: 10.1128/CMR.00081-09

Divya, K.K., Amritha, V.S., Aparna, B. and Devanesan, S. 2018. Biochemical and antioxidant properties of honey from Tetragonula iridipennis (Smith) of Southern Kerala. Indian J. Entomol, 80(3):1011-1016. doi: 10.5958/0974-8172.2018.00153.0

Eswaran, V.K.V.U., Priya, V. and Bhargava, H.R. 2015. A comparative study of the biochemical, antioxidative and anti-microbial activity of Apis and Trigona honey collected from different geographical areas of India. World Appl Sci J, 33(1): 160-167. DOI: 10.5829/ idosi. wasj. 2015.33.01.55

Ewnetu, Y., Lemma, W. and Birhane, N. 2013. Antibacterial effects of Apis mellifera and stingless bees honeys on susceptible and resistant strains of Escherichia coli, Staphylococcus aureus and Klebsiella pneumoniae in Gondar, Northwest Ethiopia. BMC Complement Altern. Med, 13(1):1-7. Doi: 10.1186/1472-6882-13-269

Fernandes, L., Ribeiro, H., Oliveira, A., Silva, A.S., Freitas, A., Henriques, M. and Rodrigues, M.E. 2020. Portuguese honeys as antimicrobial agents against Candida species. J Tradit Complement Med. doi.org/10.1016/j.jtcme. 
Frieden, T., 2010. Antibiotic resistance and the threat to public health http://www.hhs.gov/asl/testify/2010/04/t20100428b.html

Godocikova, J., Bugarova, V., Kast, C., Majtan, V. and Majtan, J. 2020. Antibacterial potential of Swiss honeys and characterisation of their bee-derived bioactive compounds. J. Sci. Food Agric, 100(1):335-342.doi.org/10.1002/jsfa.10043

Goslinski, M., Nowak, D. and Kłębukowska, L., 2020. Antioxidant properties and antimicrobial activity of manuka honey versus Polish honeys. J Food Sci Technol, 57(4):1269-1277. Doi: $10.1007 / \mathrm{s} 13197-019-04159-\mathrm{w}$

Jenkins, R.E. and Cooper, R. 2012. Synergy between oxacillin and manuka honey sensitizes methicillin-resistant Staphylococcus aureus to oxacillin. J. Antimicrob. Chemothe, 67(6):1405-1407.doi: 10.1093/jac/dks071

John-Isa, J.F., Adebolu, T.T. and Oyetayo, V.O. 2019. Antibacterial effects of honey in Nigeria on selected diarrhoeagenic bacteria. South Asian Journal of Research in Microbiology, 1:111.doi.org/10.9734

Kimoto-Nira, H. and Amano, K. 2008. Antimicrobial activity of honey produced by stingless honey bees. J. Apic. Res., 47(4):325-327. doi.org/10.1080/00218839.

Koneman EW, Allen SD, Janda WM, Schreckenberger PC and Winn WC Jr. 1992. The Enterobacteriaceae. in: colour atlas and textbook of diagnostic microbiology. 4th ed. Philadelphia: JB Lippincott. 105-84

Latkal, H., Elmansouri, S., Zakraoui, E., \& EL kadmiri, N. 2020. Antibacterial, Antioxidant and Anti-inflammatory activities of Honey. MJPAS, 6(1), 1-12. doi.org/10.48383/IMIST.PRSM/mjpas-v6i1.18114

Lye, P.Y. 2015. Interactive effect of Trigona honey and Ampicillin on Staphylococcus aureus isolates of infected wound (Doctoral dissertation, UTAR).

Michener CD. 2007. The Bees of the World. 2nd edition. Baltimore, US: Johns Hopkins University Press. 211p.

Machado De-Melo, A. A., Almeida-Muradian, L. B. D., Sancho, M. T., \& Pascual-Maté, A. 2018. Composition and properties of Apis mellifera honey: A review. J. Apic. Res, 57(1), 5-37. doi.org/10.1080/00218839.2017.1338444

Nolan V, Harrison J, Cox JA. 2019. Dissecting the antimicrobial composition of honey. Antibiotics.;8(4):251-262. doi. org/1 0.3390/anti biotics8040251

Pal, M., Teashal, B. M., Gizaw, F., Alemayehu, G., \& Kandi, V. 2020. Animals and Food of Animal Origin as a Potential Source of Salmonellosis: A Review of the Epidemiology, Laboratory Diagnosis, Economic Impact and Public Health Significance. American Journal of Microbiological Research, 8(2), 48-56.

Shahjahan, M., Halim, N.A.B.A. and NJ, N.I. 2007. Antimicrobial properties of 'kelulut' (Trigona Spp) honey. MJMS, 14(1):101-121.

Taormina, P.J., Niemira, B.A. and Beuchat, L.R. 2001. Inhibitory activity of honey against foodborne pathogens as influenced by the presence of hydrogen peroxide and level of antioxidant power. Int. J. Food Microbiol. 69(3):217-225. doi: 10.1016 /s0168$\underline{1605(01) 00505-0}$

Tumin, N., Halim, N.A., Shahjahan, M., Noor Izani, N.J., Sattar, M.A., Khan, A.H. and Mohsin, S.S.J. 2005. Antibacterial activity of local Malaysian honey. MJPS, 3(2):1-10. doi: $10.1186 / 1472-6882-9-34$

Turnidge, J. and Paterson, D.L. 2007. Setting and revising antibacterial susceptibility breakpoints. CMR, 20(3):391-408. doi: 10.1128/CMR.00047-06

Zamora Fallas, L.G. 2018. Characterization of Bioactive Constituents from Honey Produced by Costa Rican Stingless Bees. Utrecht University. doi: 10.5829/idosi.wasj.2015.33.01.55 